\title{
Thermal Analysis of Solar Air Heater with Ventilator Turbine and Fins
}

\section{Arrad Ghani Safitra, Lohdy Diana, Nu Rhahida Arini, Denny Muhammad Agil, Julfan Hafiz Farezza}

\author{
Power Plant Engineering, Politeknik Elektronika Negeri Surabaya \\ Jalan Raya ITS Sukolilo, Surabaya 60111 \\ E-mail: arradgs@pens.ac.id, lohdydiana@pens.ac.id, arini@pens.ac.id, \\ denny123@pg.student.pens.ac.id, julfanhafiz@pg.student.pens.ac.id
}

Received September 30, 2020; Revised November 4, 2020; Accepted December 8, 2020

\begin{abstract}
Solar air heater (SAH) is a renewable energy application for the drying process. SAH has a challenge to produce high performance under uncertain weather. The performance of SAH can be enhanced by providing the absorber plate by adding the fins. This study aims to evaluate the thermal performance of SAH with rectangular fins SAH at low air velocity. This study compares the performance of SAH without fins and SAH with rectangular fins. Two variations of a tilt angle of SAH are $0^{\circ}$ and $30^{\circ}$ which are observed in this study. The $\mathrm{SAH}$ uses a ventilator turbine to suck air into the collector box. The air velocity is $0.01 \mathrm{~m} / \mathrm{s}$. The method is experimental. The SAH is tested under real condition from 9 a.m. to 4 p.m. The measurement tools consist of a pyranometer, an anemometer, a temperature sensor in the inlet section, 3 sensors in the absorber plate, a sensor in the outlet section, 6 temperature sensors in the drying cabinet. The result showed the thermal efficiency of SAH with rectangular fins is $29.67 \%$ higher than SAH without fins at $0^{\circ}$ tilt of angle at noon. The thermal efficiency of SAH with rectangular fins is $25.26 \%$ higher than that of without fins at $30^{\circ}$ tilt of angle at noon.
\end{abstract}

Keywords: solar air heater, rectangular fin, low air velocity, thermal, performance.

\section{INTRODUCTION}

Solar Air Heater (SAH) has many advantages such as low cost electricity, no pollution, and easy to use. A lot of industries use SAH for various applications especially for crop and drying agricultural products[1]. The solar air heater ( $\mathrm{SAH})$ is an air heater whose principal works by using drying with the help of the sun. The heating air increases the temperature inside the drying cabinet that can reduce moisture in the product. One of type solar drying is indirect. This technique has many advantages including increased productivity because of the high drying rate, the product can be saved for periodic use because it is managed by a controller for the drying process[2]. 
The solar air heater is one of the heat exchangers types that can be applied at low temperatures. Solar air heater has a main component. It is an absorber plate that has the function to absorb solar heat radiation as a heat source. Commonly, a solar air heater uses a flat absorber plate. It still has low efficiency [3]. The thermal efficiency of a solar air heater depends on useful energy that can be absorbed by absorber plate. The useful energy is influenced by heat transfer inside a solar collector. The heat transfer can be increased by adding obstacles, fins, and baffles on the absorber plate surface. Several researches were carried out to increase heat transfer inside a solar collector. The research only focused on high air velocity. It because the solar air heater used a blower. Actually, the blower can decrease the value of a solar air heater as green energy. It because the blower needs electricity to operate. The solar air heater seldom investigates in low air velocity. The solution to produce low air velocity is the application of a ventilator turbine. The ventilator turbine is driven by wind and buoyancy force from airflow from inside the drying cabinet that has a high temperature. The application of a ventilator turbine in the solar air heater can reduce cost operation. It because the ventilator turbine does not need electricity. The ventilator turbine produces low air velocity that can make the heated process longer than a solar air heater that uses a blower.

This study tried to achieve the performance of SAH experimentally and analyze the thermal performance of a solar air heater by calculating outlet temperature, thermal efficiency depends on solar intensity. The SAH used a ventilator turbine. It had a purpose to reduce electric costs. The variations of this study were the absorber plate and tilt angle of SAH. The absorber plate used a flat plate and a flat plate with rectangular fins that arranged staggered formation. The tilt angles were 0 degrees and 30 degrees from the horizontal axis. This paper research aims to study experimentally SAH performance to obtain high thermal efficiency by adding rectangular fins at the absorber plate in various configurations.

\section{RELATED WORKS}

Some research about solar air heater had been carried out to produce a new solar air heater that had high performance. Experimental study of flat plate SAH used steel plate $1.202 \times 0.495 \mathrm{~m}^{2}$ and $0.006 \mathrm{~m}$ for the thickness. The experiment compared Flat Plate Solar Air Heater (FPSAH) and Spherical Dimple Plate Solar Air Heater (SDPSAH). The result showed that SDPSAH had high efficiency $23.45 \%$ greater than FPSAH [3]. The flat plate solar air heater performance is also evaluated in the actual condition. The result showed the maximum thermal efficiency was $56 \%$ when the mass flow rate of $0.042 \mathrm{~kg} / \mathrm{s}$ [4]. This tropical country produced ginger and pepper as agricultural products. On a daily basis, ginger needs a drying process because of the abundant amount of solar heat in the country, some researchers try to build a solar dryer. The solar dryer uses a heat transfer concept especially forced convection. It consists of glass, absorber plate, and fan. It was tested 
experimentally under real conditions begin from 9:00 am to 6:00 pm. The result showed the efficiency of solar dryers was $11.53 \%$ until $20.87 \%$ [5]. It had $10 \%$ until $65 \%$ thermal efficiency with good quality of copra [6]. There were many ways to bring out innovation to enhance the performance of SAH such as insert fins, baffles as vortex generators to increase heat transfer. The research about the evaluation of solar air heater with louvered fins carries out to know the performance.

The other research investigated the influence of turbulence generators on the flat plate thermal performance of SAH. It used a cylindrical shape generator [7]. The comparison solar air heater used longitudinal fins and without fin also carried out. The result showed the thermal efficiency is $40.02 \%$ for SAH with fins and $34.92 \%$ for SAH without fins [1]. The same result was showed by a solar air heater that used aluminum foam obstacles. It had a thermal efficiency of $77 \%$. It was higher than the flat plate solar air heater $37 \%$ [8]. The experimental study also analyzed heat transfer characteristics for a solar air heater that used T-ribs as fins on an absorber plate surface [9].

There are some problems with solar drying in the actual condition such as uncontrolled weather, at night condensation happens thus moisture will back to the drying products. It means the insulation is needed to reduce heat loss [10]. The research about solar water tanks was carried out to decide the best configuration of naturally insulating material for the performance of the tank. The result showed that a good configuration of insulating material was brick and soil. The holding time of water temperature was up to 24 hours to hold hot water temperature at $45^{\circ} \mathrm{C}$ [11]. Several same types of research are also carried out. The base insulating for the thermal insulation system was an innovation. The essential presented that insulation from polyester fibers had matching characteristics with minerals [12], [13].

\section{ORIGINALITY}

Based on several previous studies, there was a challenge to find an innovation about a solar air heater with high performance. Several previous studies have become a reference to produce new variations of this research. This research purpose was to increase performance signed by the thermal efficiency of this special equipment. This research about a solar air heater that combined used rectangular fins on the absorber plate. The fins were made from an aluminum sheet. It has a function increase thermal performance The SAH operated at low air velocity. It because the SAH used a ventilator turbine. It was operated by natural wind velocity and heat temperature from the drying cabinet that produces pressure to drive turbine blades. A ventilator turbine did not need electricity.

\section{THERMAL PERFORMANCE ANALYSIS}

Mass flow rate is a mass of air in kg for each time in second, it can be calculated to follow this equation: 
$\dot{m}=\rho \cdot v \cdot A$

Where $\rho$ is air density in $\left(\mathrm{kg} / \mathrm{m}^{3}\right), \mathrm{v}$ is air velocity in $(\mathrm{m} / \mathrm{s})$ when enters solar air heater and $A$ is an entrance area in $\left(\mathrm{m}^{2}\right)$. The temperature difference is the difference temperature taken between air temperature outlet and air temperature enter, it can be calculated using this equation:

$$
\Delta T=T_{\text {out }}-T_{\text {in }}
$$

Tin is the temperature of the air when air enters to honeycomb before the solar air heater channel. Useful heat is the sum of heat that is produced by a solar air heater, it can be written:

$$
Q_{u}=\dot{m} \cdot c_{p} \cdot\left(T_{\text {out }}-T_{\text {in }}\right)
$$

Where $m$ is air mass flow, $C_{p}$ is specific heat, and the temperature difference between $\mathrm{T}_{0}$ is outlet air temperature, $\mathrm{T}_{\mathrm{i}}$ is inlet air temperature. Solar air heater thermal efficiency is a ratio of useful energy to solar radiation and solar air heater area, it can be expressed as [14]:

$$
\eta=\frac{Q_{u}}{I_{T} \cdot A_{c}}
$$

Where $A_{c}$ is the effective collector area $\left(\mathrm{m}^{2}\right)$, $\mathrm{I}_{\mathrm{T}}$ is Solar radiation intensity $\left(\mathrm{W} / \mathrm{m}^{2}\right)$. The percent of decreasing mass is calculated as follows:



Where Dec. mass is Decreasing mass (\%), inmass is initial mass (g), endmass is end mass (g).

\section{EXPERIMENT AND ANALYSIS}

(a)

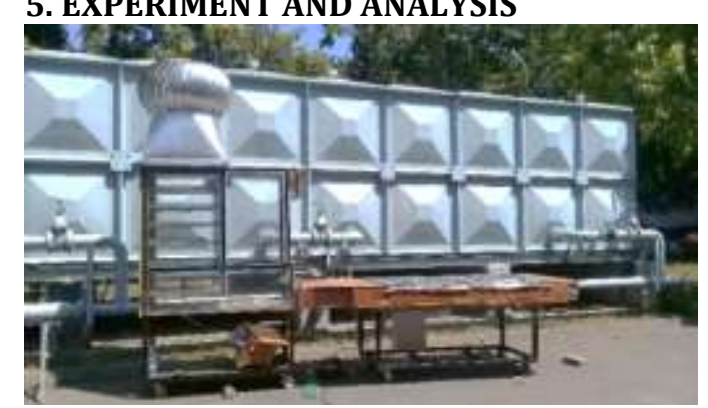

(b)

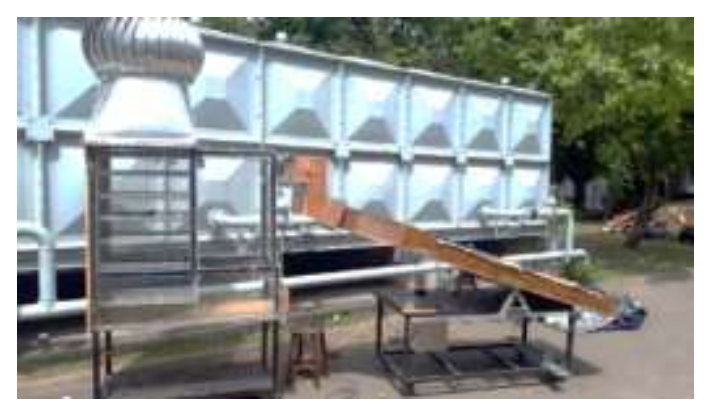

Figure 1. The experiment apparatus (a) without tilt angle (b) with tilt angle 
The absorber plate used a flat plate with two variations of the surface. There were without fins and with rectangular fins were arranged staggered on the absorber plate surface. An experimental analysis was build of two kind of variation absorber plates of SAH. In other words, this work also analyzed the optimum installed position as shown in Figure 1.

A solar air heater had size those were $0.9 \mathrm{~m}$ width, $1.5 \mathrm{~m}$ length, and $0.15 \mathrm{~m}$ height. It consisted of several constituent components among others: A honeycomb was made from several small pipes. The size followed a standard that the length of pipes was four times the diameter [15] It was arranged such as honeycomb. It had a function to make airflow be uniform flow before entered the SAH channel; A channel composed of glass in the top position. It had a thickness of $5 \mathrm{~mm}$, transmittance of 0.9 , absorption of 0.05 ; Inside channel was installed by an aluminum plate that coated black color. It had $3 \mathrm{~mm}$ thick; the Solar air heater channel was covered by insulating material. It consisted of glass wool and wood. The insulation material had a purpose to reduce heat loss from a solar air heater to the surrounding; The outlet channel was made from wood. It connected to a drying cabinet; A drying cabinet was installed after the outlet channel. It had a function to put drying objects or food into the drying process. It had three racks; A ventilator turbine was made from an aluminum plate. It had a diameter of $0.45 \mathrm{~m}$. It was installed on the top of the drying cabinet. It can be seen in Figure 1. A ventilator turbine had a function to circulate airflow from the inlet to the drying cabinet.

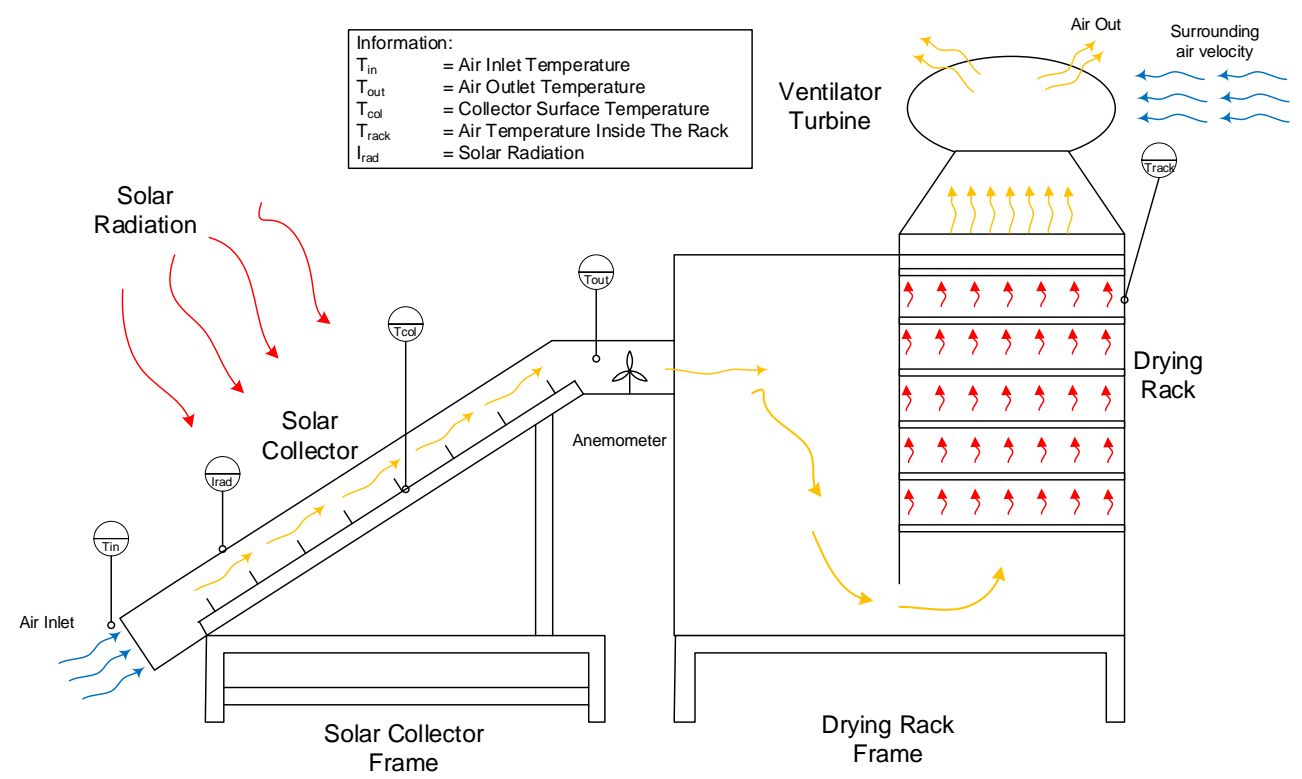

Figure 2. The schematic system of SAH and measurement instruments position in SAH. 
The working principle of a solar air heater was surrounding air inhaled by a ventilator turbine. Surrounding air entered to honeycomb and then entered the solar air heater channel. In this channel, the air was having a heating process. The heating process source was from solar heat transmitted by the glass and then solar heat was absorbed by the aluminum plate as an absorber plate. Heat transfer happened on this channel. The heated airflow went out to the outlet channel toward the drying cabinet and ready to dry food inside the drying cabinet. The system of SAH and measurement instruments in the SAH can be seen in Figure 2.

A solar air heater installed position is in the north. The location in Politeknik Elektronika Negeri Surabaya (-7.27 S, 112.79 E). The experiment was carried out from 27th November to 2nd December 2019. The duration of getting data from 9:00 am to 4:00 pm, western Indonesian time. The collector was tested horizontally as an initial condition and $30^{\circ}$ as the best tilt angle based on weather conditions also the movement of the sun in the Politeknik Elektronika Negeri Surabaya [16]. The collector was tested in sunny conditions. The K-type thermocouples were instrumented for measuring temperatures at the inlet and outlet of the collector, and the ambient temperature. Several K-type thermocouples measuring instruments are put in a solar air heater system. It consisted of temperature sensors using a thermocouple. There were 15 sensors inside the collector for measuring the temperature of air: 1 outside for ambient temperature, 3 in an inlet, 3 on absorber plate, 3 in an outlet, 3 inside drying cabinet. The pyranometer is used to measure solar intensity. The anemometer is used to measure air velocity. The air velocity was $0.01 \mathrm{~m} / \mathrm{s}$. The specification of measurement device can be seen in Table 1 . The dimension of the rectangular fin was diameter (d) of $200 \mathrm{~mm}$, thickness (t) of $3 \mathrm{~mm}$, height (h) of $19 \mathrm{~mm}$, spacing from the center of the fin to fin for longitudinal direction (s) $200 \mathrm{~mm}$, and spacing fin to fin for transversal direction (d')100 mm. The detail of a fin geometry can be seen in Figure 3.

Table 1. Specification of Measurement Device

\begin{tabular}{|c|c|c|}
\hline \multicolumn{1}{|c|}{ Measurement device } & \multirow{2}{*}{ Value } & \multirow{2}{*}{ Unit } \\
\cline { 1 - 1 } Pyranometer & $0-2000$ & $\mathrm{~W} / \mathrm{m}^{2}$ \\
\hline$-\quad$ Intensity range & 0.15 & $\%$ \\
\hline$-\quad$ Stability & $<10$ & $\%$ \\
\hline Anemometer & $0-30$ & $\mathrm{~m} / \mathrm{s}$ \\
\hline$-\quad$ Velocity range & 5 & $\%$ \\
\hline$-\quad$ Accuracy & & \\
\hline Thermocouple & $-55-200$ & ${ }^{\circ} \mathrm{C}$ \\
\hline$-\quad$ Temperature range & 1 & $\%$ \\
\hline$-\quad$ Tolerance & & \\
\hline
\end{tabular}

The sponge was used as a drying object. In the initial condition, the dry sponge was wet by 45 grams of water then the mass of the sponge was 
weighed and noted as initial mass. Some wet sponges put in the drying cabinet were three sponges for each rack. When 4:00 pm mass sponges weighed again and noted as end mass. Equation 5 was used to calculate the percent of decreasing mass. This current work was done for a solar air heater used rectangular fins. It was made from an aluminum plate with $1 \mathrm{~mm}$ thickness and had been layer with black color to increase the emissivity. It was arranged staggered on the absorber plate surface. The shape of the absorber flat plate can be seen in Figure 4.

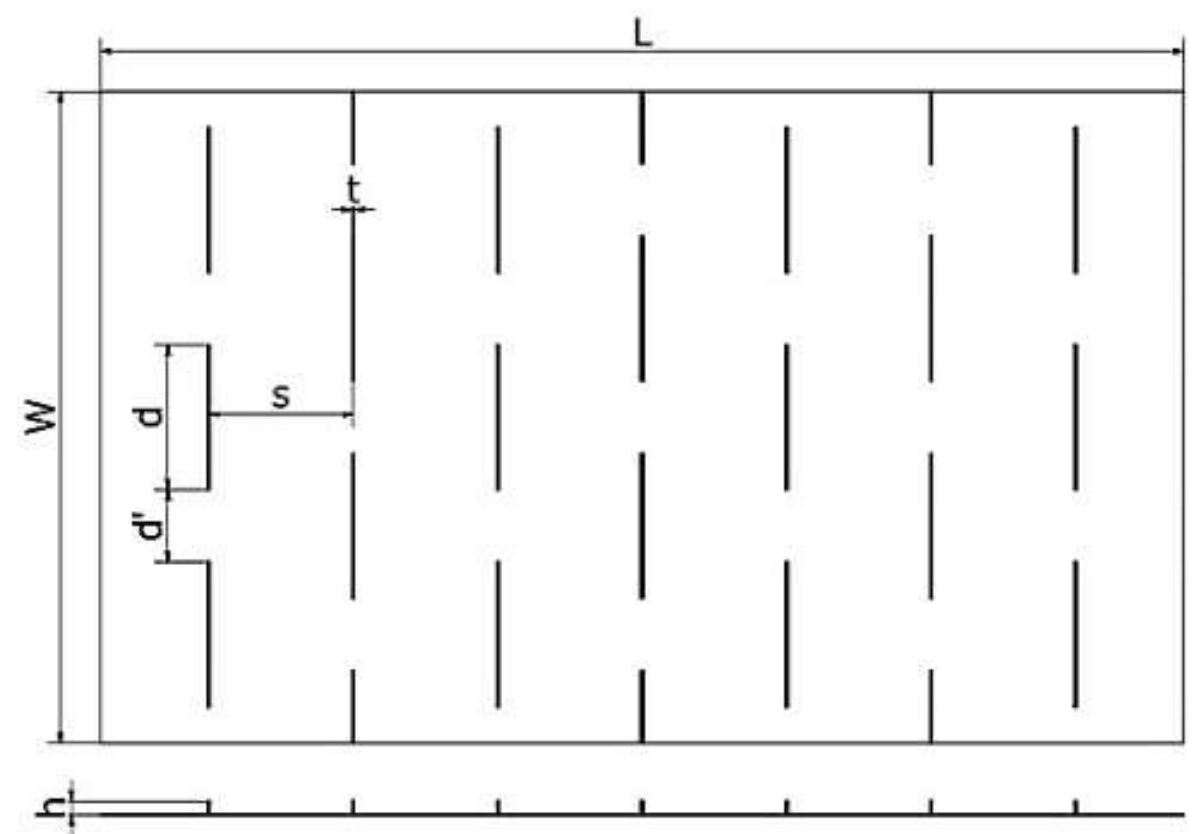

Figure 3. The detail of fin geometry

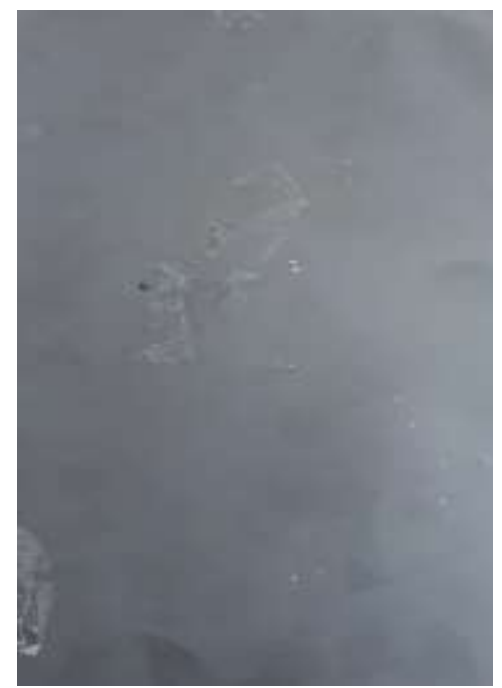

(a)

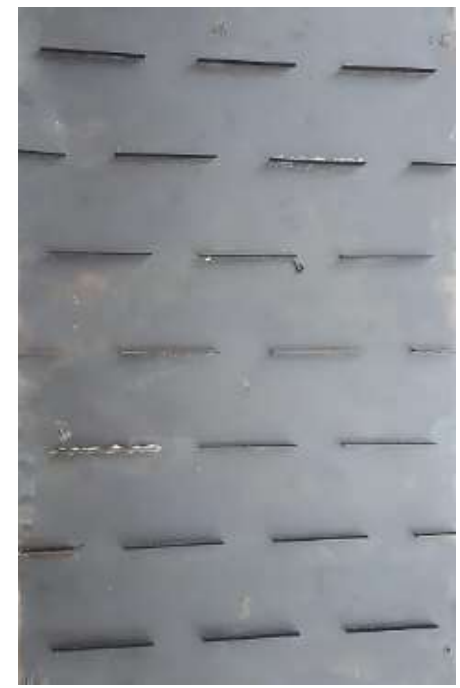

(b)

Figure 4. The shape of absorber flat plate (a) without fin, (b) with rectangular fins

The essentials of this experimental research will discuss the interesting point of thermal performance of this equipment which variations are already 
listed in the method chapter. Figure 5(a) presents the hourly of the ambient temperature, inlet temperature, and outlet temperature along time of the day on the initial position. The ambient temperature was the air surrounding temperature in the area where the equipment in this research was installed. The mass flow rate was $0.033 \mathrm{~kg} / \mathrm{s}$, and the solar radiation achieved each hour was presented during the experiments by the Figure 5 (a)-(d). The best solar radiation was achieved as $965 \mathrm{~W} / \mathrm{m}^{2}$. The outlet air temperature had a parabolic trend. As expected, it increased in the morning then reached the top at 12.00 and drop in the afternoon. The increased air temperatures it signed air temperature inside the channel undergoing a heating process from inlet to outlet. It also depended on solar intensity. The difference between the daily air temperature ( $\mathrm{Ta}$, in and $\mathrm{Ta}$, out) variated without fins collector at $0.033 \mathrm{~kg} / \mathrm{s}$ mass flow rate was reached as $19^{\circ} \mathrm{C}$. When the absorbing surface temperatures reached $71^{\circ} \mathrm{C}, 85^{\circ} \mathrm{C}, 98^{\circ} \mathrm{C}$ for three-point measurement in surface collector plate.

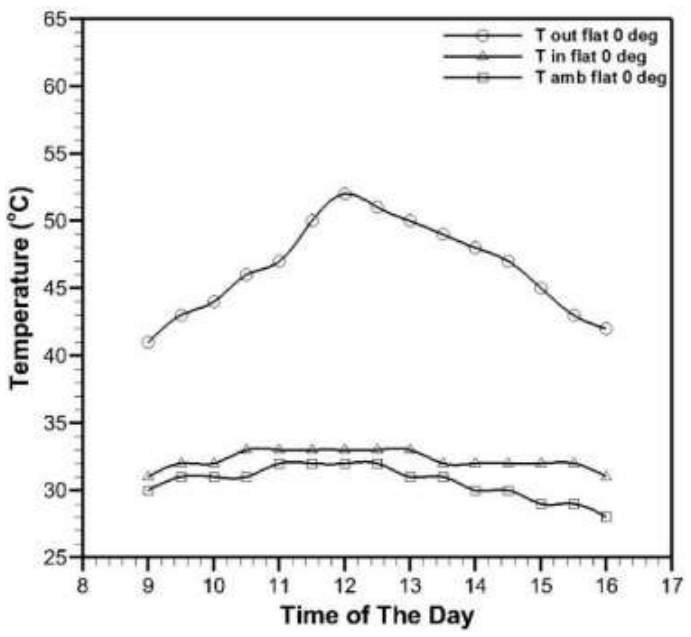

(a)

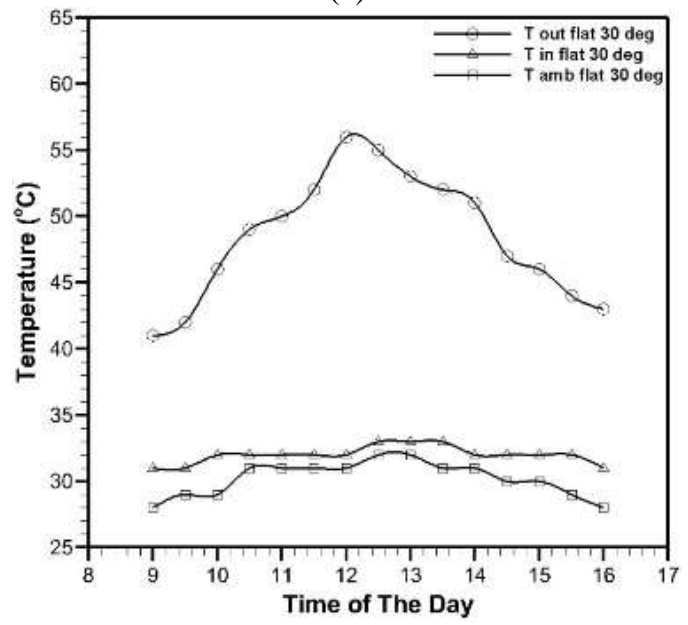

(c)

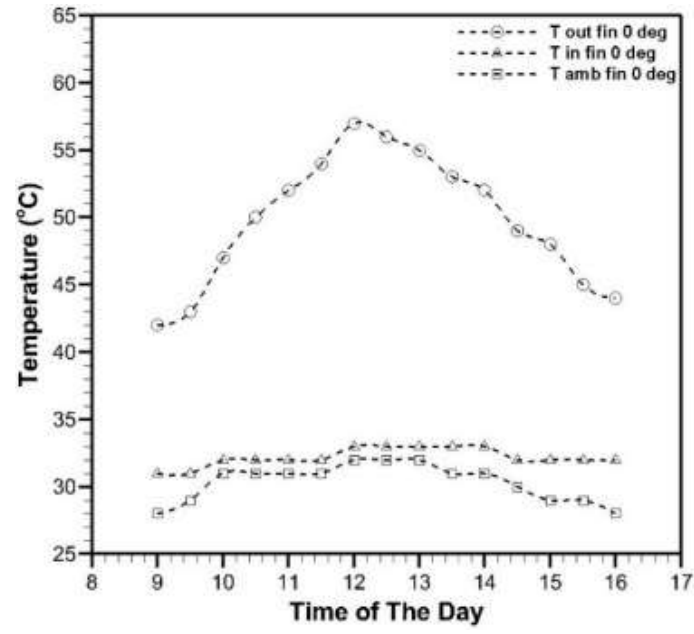

(b)

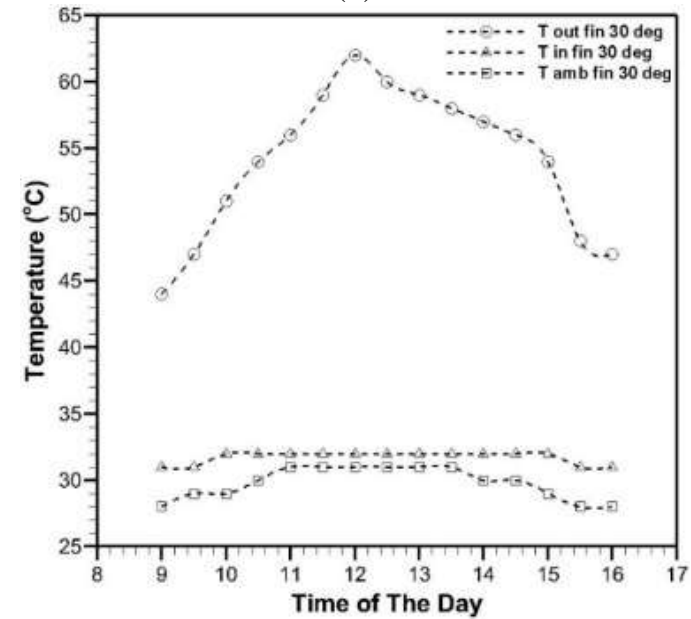

(d)

Figure 5. The ambient, inlet, outlet air temperature hourly for experiment (a) without fins, with $0^{\circ}$ tilt angle, (b). with fin, with $0^{\circ}$ tilt angle, (c) without fins, with $30^{\circ}$ tilt angle, (d) with fins, with $30^{\circ}$ tilt angle 
The inlet temperature is air temperature when entering a solar air heater. The outlet temperature is air temperature when going out solar air heater. Based on Figure 5(b), the minimum ambient temperature was $28^{\circ} \mathrm{C}$ and the maximum value was $32^{\circ} \mathrm{C}$. The minimum inlet temperature was $31^{\circ} \mathrm{C}$ and the maximum value of inlet temperature was $33^{\circ} \mathrm{C}$. Based on the explanation, it can be said the value of ambient temperature and inlet temperature are relatively the same. It also showed by the same graphic trend between ambient temperature and inlet temperature. Base on Figure 5 (b), it can be seen the different value of outlet air temperature for solar air heater which variation is already listed in the method section when solar air heater was installed in 0 angles from horizontal. The SAH with rectangular fins had the outlet air temperature result was better than SAH without fins with the maximum temperature of $52^{\circ} \mathrm{C}$ at $12: 00 \mathrm{pm}$ while the object of this research without fins had maximum outlet air temperature of $57^{\circ} \mathrm{C}$ at $12: 00$ pm.

Figure 5(c) presents the variation of the ambient temperature each hour, inlet temperature, and outlet temperature along time of the day in a 30degree position. The best solar radiation was achieved as $965 \mathrm{~W} / \mathrm{m}^{2}$. The outlet air temperature had a parabolic trend. As expected, it becomes rises in the morning to the top ones at 12.00 and tries to drop at the noon. Daily mean temperatures on the absorbing surface were gotten as $82^{\circ} \mathrm{C}, 92^{\circ} \mathrm{C}$, $105^{\circ} \mathrm{C}$ for three-point measurement in surface collector plate. The difference between the mean daily air temperature (Ta, in and $\mathrm{Ta}$, out) in the SAH without fins reached $0.033 \mathrm{~kg} / \mathrm{s}$ mass flow rate was achieved as $24^{\circ} \mathrm{C}$.

It had the maximum outlet temperature of $61^{\circ} \mathrm{C}$ then Figure $5(\mathrm{~d})$. It had the highest outlet air temperature of $62^{\circ} \mathrm{C}$ when a solar air heater was installed at angle $30^{\circ}$. Based on the explanation, it can be said that the tilt angle of a SAH influence outlet air temperature. It depended on the absorber plate that got much solar heat when the position is $30^{\circ}$ tilt angle. The outlet air temperature depended on an absorber temperature. The performance of this equipment in this research was evaluated by thermal efficiency. Based on Figure 5, the SAH with rectangular fins had an increasing outlet temperature of $8.77 \%$ in 0 angles from horizontal and $9.67 \%$ in a 30degree position greater than The SAH without fins in the noon. It meant fins could increase outlet temperature [17].

Figure 6 (a) and (b) served the essential of the ones with and without fins at air mass flow rate $0.033 \mathrm{~kg} / \mathrm{s}$. This parameter made sense to analyzed the performance of this equipment, it was discovered from the figures that efficiency became a good line linearly with the intensity of the sun as a function of time. It can be seen that the collectors with fins were more efficient than without fins. 


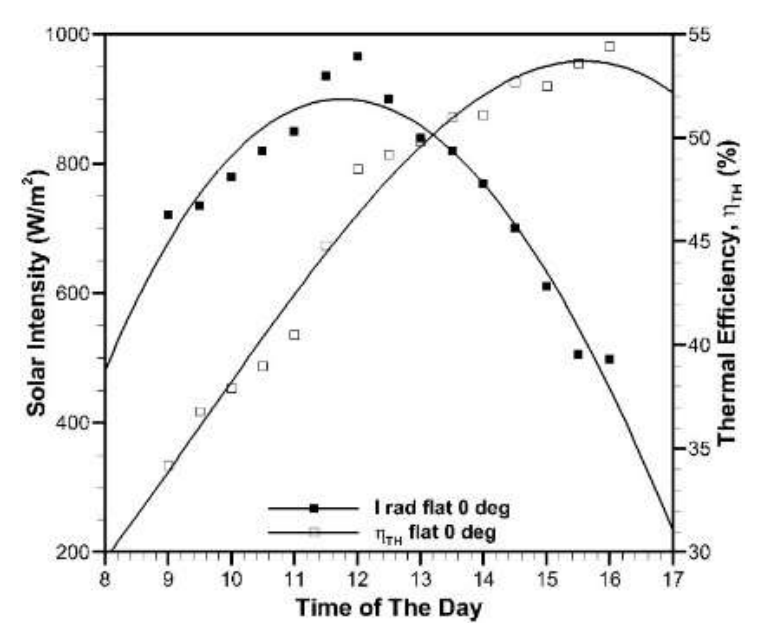

(a)

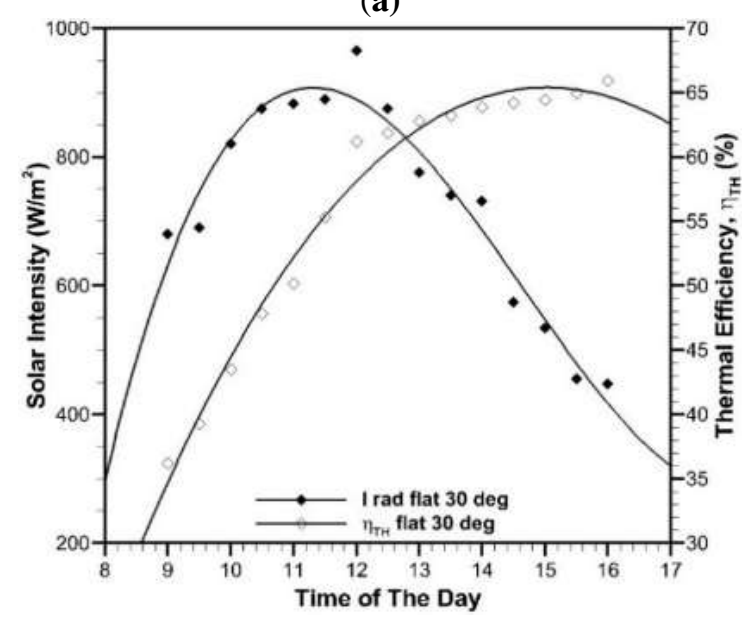

(c)

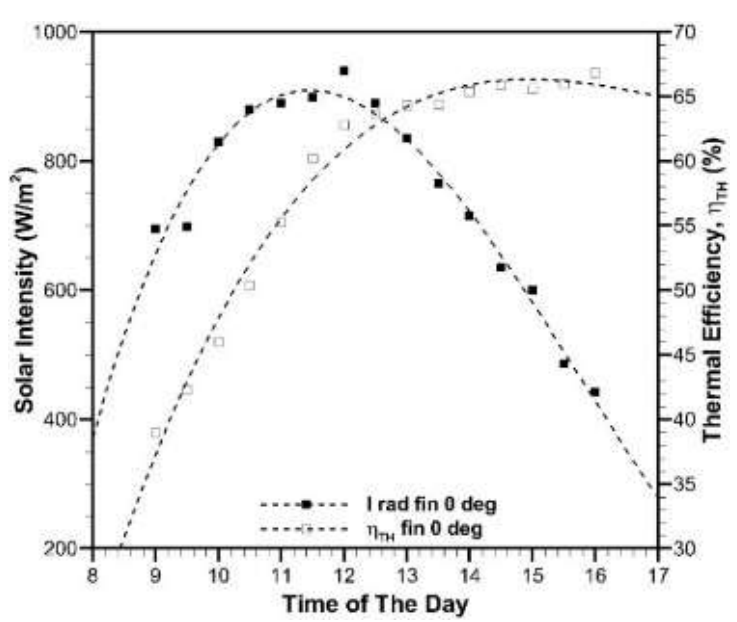

(b)

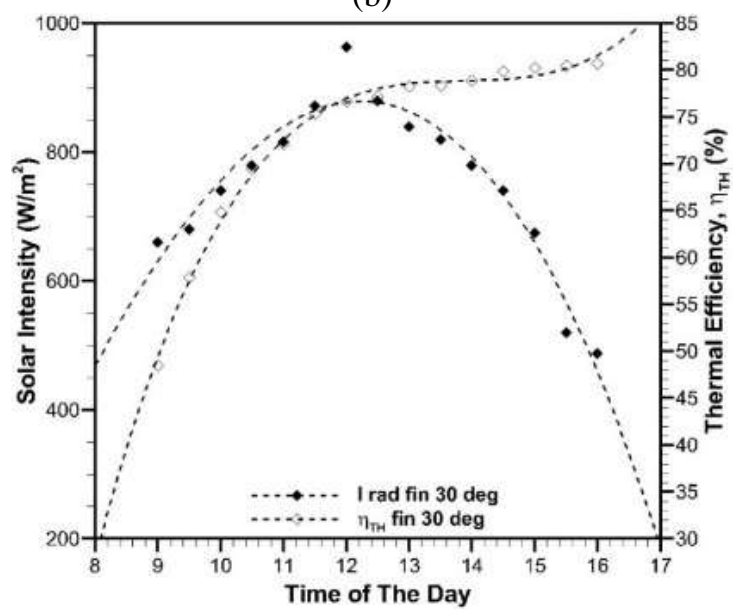

(d)

Figure 6. Thermal efficiency throughout the day with varying solar intensities for solar air heater (a) without fins, with $0^{\circ}$ tilt angle, (b). with fin, with $0^{\circ}$ tilt angle, (c) without fins, with $30^{\circ}$ tilt angle, (d) with fins, with $30^{\circ}$ tilt angle

Figure 6(a) shows the parameter essential in this research throughout of day for flat plate SAH without fins and a solar air heater had tilt angle $0^{\circ}$ from horizontal. In this figure can be seen solar intensity had a parabolic trend start from $720 \mathrm{~W} / \mathrm{m}^{2}$ at 9:00 am increased slowly until had the maximum value of $965 \mathrm{~W} / \mathrm{m}^{2}$ at 12:00 pm and decreased fast until had the minimum value of $498 \mathrm{~W} / \mathrm{m}^{2}$ at 4:00 $\mathrm{pm}$. The same trend was shown by the thermal efficiency of this equipment. Useful heat is influenced by temperature different from inlet to outlet. Thermal efficiency increased continuously from 9:00 am 34.2\% to 4:00 pm 54.4\%.

Figure 6(b) presents the intensity of the sun and heat efficiency throughout of day for this equipment in this research with rectangular fins were arranged staggered and a solar air heater had tilt angle $0^{\circ}$ from horizontal. In this figure can be seen solar intensity a parabolic trend started from $695 \mathrm{~W} / \mathrm{m}^{2}$ at 9:00 am increased slowly until had the maximum value of $940 \mathrm{~W} / \mathrm{m}^{2}$ at 12:00 $\mathrm{pm}$ and decreased until had the minimum value of 442 $\mathrm{W} / \mathrm{m}^{2}$ at $4: 00 \mathrm{pm}$. 
Figure $6(\mathrm{c})$ shows when a tilt angle of $30^{\circ}$, the minimum thermal efficiency was $35.27 \%$ and the maximum thermal efficiency was $55.83 \%$. Figure $6(d)$ had a tilt angle of $30^{\circ}$, the minimum thermal efficiency was $48.49 \%$ and the maximum thermal efficiency was $80.71 \%$. Based on Figure 6(d), it can be seen as the highest value of thermal efficiency when tilting angle of $30^{\circ}$. Based on Figures 6 (b) and 6 (d), the thermal efficiency of SAH with rectangular fins at tilt angle of $30^{\circ}$ was about $15 \%$ higher than at tilt angle of $0^{\circ}$. It due to solar air heater gets solar radiation longer than other tilt angles. Position of 30 tilt angle get more radiation for all day because based on last research for the best position in Politeknik Elektronika Negeri Surabaya location (-7.27 S, 112.79 E) the collector should be setting in 30 tilt angle. The same trend is shown by the thermal efficiency of equipment in this research. Thermal efficiency got from equation (4). Useful heat is influenced by temperature different from inlet to outlet. Thermal efficiency increased continuously from 9:00 am 39\% to $4: 00 \mathrm{pm} 66.8 \%$. This study tried to relate thermal efficiency between variations that were already listed in the experiment and analysis section. It can be seen based on Figure 6(c) and (d). The solar intensity when experiment with the plate in this experiment without fins was higher than vice versa. It had a difference of $25 \mathrm{~W} / \mathrm{m}^{2}$. Based on the figure SAH with rectangular fins were arranged staggered had thermal efficiency $20 \%$ higher than solar air heater without fins at the noon. It can be said fins on the absorber plate surface can help solar air heater to increase thermal efficiency. It due to fins can make airflow becomes turbulent. The turbulent airflow will increase heat transfer [18], [19]. The thermal efficiency will increase linearly with the increase of heat transfer. The result showed the thermal efficiency of SAH with rectangular fins is $29.67 \%$ higher than without fins at $0^{\circ}$ tilt of angle at noon. The thermal efficiency of SAH with rectangular fins is $25.26 \%$ higher than without fins at $30^{\circ}$ tilt of angle at noon.

The analysis in this study continued by calculated percent decreasing the water content of some sponges put inside the drying cabinet where this cabinet had three racks. There were nine sponges where three sponges in each rack. Table 1 shows the average value of percent decreasing water content for nine sponges. The initial mass of sponges was weighed at 9:00 am and the weight of all sponges was set the same for all variations. The final mass of sponges was weighed at 4:00 pm. Based on Table 2, Sponges undergoing the highest decreasing of mass when using flat plate SAH with the parameter explain in the method chapter, with a $30^{\circ}$ tilt angle. In the condition, the temperature of the cabinet was $44^{\circ} \mathrm{C}$. It was the highest according to Table 3 and based on Table 4 the relative humidity was 15\%. It was the lowest of the others. It also due to when sponger drying using flat plate ones, with a $30^{\circ}$ tilt angle, the SAH has the highest thermal efficiency. It was $80.71 \%$. Based on Table 2 , the SAH with fins could reduce water content until $25.92 \%$ than the SAH without fins in a 30degree position. It signed the SAH had high thermal efficiency could increase the percent decreasing water 
content of drying objects fast then a solar air heater had low thermal efficiency. The high temperature in a drying cabinet and low relative humidity in the drying cabinet also could increase the percentage of decreasing water content. It can be seen in Table 3 and Table 4.

Table 2. Mass drying product

\begin{tabular}{|c|c|c|c|c|c|}
\hline \multirow{2}{*}{ Condition } & \multirow{2}{*}{ Time } & \multicolumn{4}{|c|}{ Mass (gram) } \\
\cline { 3 - 6 } & & ${\text { Flat } \mathbf{0}^{\mathbf{0}}}$ & Flat 30 $^{\mathbf{0}}$ & Fin 0 $^{\mathbf{0}}$ & Fin 30 $^{\mathbf{0}}$ \\
\hline $\begin{array}{c}\text { Inside } \\
\text { (using SAH) }\end{array}$ & Start drying & 50 & 50 & 50 & 50 \\
\cline { 2 - 6 } & Finish drying & 34 & 27 & 25 & 20 \\
\hline $\begin{array}{c}\text { Outside } \\
\text { (conventional) }\end{array}$ & Start drying & 50 & 50 & 50 & 50 \\
\cline { 2 - 6 } & Finish drying & 36 & 37 & 36 & 36 \\
\hline
\end{tabular}

Table 3. Temperature of drying cabinet

\begin{tabular}{|c|c|c|c|c|c|}
\hline \multirow{2}{*}{ Condition } & \multirow{2}{*}{ Time } & \multicolumn{4}{|c|}{ Temperature $\left({ }^{\circ} \mathrm{C}\right)$} \\
\hline & & Flat $0^{\circ}$ & Flat $30^{\circ}$ & Fin $0^{\circ}$ & Fin $30^{\circ}$ \\
\hline \multirow{2}{*}{$\begin{array}{c}\text { Inside } \\
\text { (using SAH) }\end{array}$} & Start drying & 38 & 38 & 39 & 41 \\
\hline & Finish drying & 39 & 40 & 41 & 44 \\
\hline \multirow{2}{*}{$\begin{array}{c}\text { Outside } \\
\text { (conventional) }\end{array}$} & Start drying & 31 & 31 & 31 & 31 \\
\hline & Finish drying & 31 & 31 & 32 & 31 \\
\hline
\end{tabular}

Table 4. Relative humidity of drying product

\begin{tabular}{|c|c|c|c|c|c|}
\hline \multirow{2}{*}{ Condition } & \multirow{2}{*}{ Time } & \multicolumn{4}{|c|}{ Relative Humiditv (\%) } \\
\cline { 3 - 6 } & & Flat 0 $^{\mathbf{0}}$ & Flat 30 $^{\mathbf{0}}$ & Fin 0 $^{\mathbf{0}}$ & Fin 30 $^{\mathbf{0}}$ \\
\hline Inside & Start drying & 61 & 60 & 58 & 57 \\
\cline { 2 - 6 } (using SAH) & Finish drying & 19 & 19 & 20 & 15 \\
\hline $\begin{array}{c}\text { Outside } \\
\text { (conventional) }\end{array}$ & Start drying & 70 & 69 & 70 & 70 \\
\cline { 2 - 6 } & Finish drying & 68 & 68 & 69 & 69 \\
\hline
\end{tabular}

\section{CONCLUSION}

The result shows at 12:00 pm the flat plate solar air heater without fins with tilt angle $0^{\circ}$ had the lowest air outlet temperature $52^{\circ} \mathrm{C}$ and thermal efficiency $48.47 \%$. While the flat plate SAH with rectangular fins was arranged staggered with a $30^{\circ}$ tilt angle had the highest air outlet temperature of $62^{\circ} \mathrm{C}$ and thermal efficiency of 76,68\%. The thermal efficiency of SAH with rectangular fins is $29.67 \%$ higher than without fins at $0^{\circ}$ tilt of angle at noon. The thermal efficiency of SAH with rectangular fins is $25.26 \%$ higher than without fins at $30^{\circ}$ tilt of angle at noon. It signed fins influenced to airflow become a turbulent flow that increases heat transfer. The high heat transfer can increase thermal efficiency as the performance of a solar air heater. The tilt angle also influences the distribution of solar heat to increase performance. This research still needs to be improved by simulating the airflow in the SAH channel to determine the air temperature distribution. 


\section{Acknowledgements}

The authors want to say thank you to Politeknik Elektronika Negeri Surabaya for event support, for the Thermal Laboratory assistant for technical support, and also for Power Plant Engineering Study Program.

\section{REFERENCES}

[1] S. Chand and P. Chand, Parametric study on the performance of solar air heater equipped with louvered fins $\dagger$, vol. 32 , no. 8 , pp. 3965-3966, 2018.

[2] A. B. Lingayat, V. P. Chandramohan, V. R. K. Raju, and V. Meda, A review on indirect type solar dryers for agricultural crops - Dryer setup, its performance, energy storage and important highlights, Appl. Energy, vol. 258, no. May 2019, p. 114005, 2020.

[3] A. Perwez and R. Kumar, Thermal performance investigation of the flat and spherical dimple absorber plate solar air heaters, Sol. Energy, vol. 193, no. September, pp. 309-323, 2019.

[4] A. Rai and V. Sachan, PERFORMANCE STUDY, no. July 2015, 2018.

[5] M. Kumar, Experimental forced solar thin layer ginger drying, Facta Univ. Ser. Mech. Eng., vol. 14, no. 1, pp. 101-111, 2016.

[6] G. Padmanaban, P. K. Palani, and M. Murugesan, Performance of a desiccant assisted packed bed passive solar dryer for copra processing, Therm. Sci., vol. 21, pp. 419-426, 2017.

[7] S. Colin, International Journal of Heat and Technology: Foreword, Int. J. Heat Technol., vol. 26, no. 1, p. 107, 2008.

[8] G. Kollektörlerİnİn, I. Performansinin, and D. Anali̇zİ, Experimental Analysis of Thermal Performance of Solar Air Collectors with Aluminum Foam Obstacles, Isı Bilim. ve Tek. Derg., vol. 35, no. 1, pp. 11-20, 2015.

[9] A. K. Barik, A. Mohanty, J. R. Senapati, and M. M. Awad, Constructal design of different ribs for thermo-fluid performance enhancement of a solar air heater (SAH), Int. J. Therm. Sci., vol. 160, no. October 2020, p. 106655, 2021.

[10] G. Deshmukh, P. Birwal, R. Datir, and S. Patel, Thermal Insulation Materials: A Tool for Energy Conservation, J. Food Process. Technol., vol. 08, no. 04, pp. 8-11, 2017.

[11] A. G. Safitra, L. Diana, and K. D. Ariswanda, Performance Analysis of Storage Tank with Natural Insulating Material in Solar Water Heater System, 2018 Int. Electron. Symp. Eng. Technol. Appl. IES-ETA 2018 - Proc., no. 1, pp. 113-116, 2019.

[12] R. Drochytka, M. Dvorakova, and J. Hodna, Performance Evaluation and Research of Alternative Thermal Insulation Based on Waste Polyester Fibers, Procedia Eng., vol. 195, pp. 236-243, 2017.

[13] M. Ali et al., Thermal and acoustic characteristics of novel thermal insulating materials made of Eucalyptus Globulus leaves and wheat straw fibers, J. Build. Eng., vol. 32, p. 101452, 2020. 
[14] J. A. Duffie and W. A. Beckman, Solar engineering of thermal processes. Wiley, 2013.

[15] R. American Society of Heating and A.-C. Engineers, ASHRAE Standard Methods of Testing to Determine the Thermal Performance of Solar Collectors, Report, vol. 1986, no. Ra 91, 1986.

[16] A. G. Safitra, F. H. Sholihah, and I. N. Fauziyyah, Experimental study of slope angle and low e glazing effects on photovoltaic module, IOP Conf. Ser. Earth Environ. Sci., vol. 105, no. 1, 2018.

[17] G. Murali, A. T. M. Sundari, S. Raviteja, S. Chanukyachakravarthi, and M. Tejpraneeth, Experimental study of thermal performance of solar aluminium cane air heater with and without fins, Mater. Today Proc., vol. 21, no. xxxx, pp. 223-230, 2020.

[18] L. Diana, A. G. Safitra, D. Ichsani, and S. Nugroho, CFD Analysis of Airflow Through Prism Obstacles Inside Solar Air Heater Channel, J. Phys. Conf. Ser., vol. 1577, no. 1, 2020.

[19] A. G. Safitra, L. Diana, and A. N. Azizah, CFD analysis of thermal improvement in flat plate solar air heater with rectangular baffles, 2019 Int. Conf. on Engineering, Technology and Industrial Appl. ICETIA 2019, pp. 1-12, 2019. accepted. 